Vol. 2, No. 2, 2021

\author{
Olena Barabash ${ }^{1}$, Ganna Weigang ${ }^{2}$, Kateryna Komar ${ }^{2}$ \\ 1. National Transport University \\ 1, Omelianovicha-Pavlenko Ave., Kyiv, 01010, Ukraine \\ 2. Banking University \\ 61, V. Chornovola Ave., Lviv, 79020, Ukraine \\ (C) O.Barabash, G. Weigang, K. Komar, 2021 \\ https://doi.org/.10.23939/tt2021.02.042
}

\title{
FORMATION OF TRAFFIC SAFETY PROFILE IN CENTRAL PARTS OF THE CITY AND ITS INFORMATIONAL PROTECTION
}

\begin{abstract}
Summary. Nowadays, there is a difference between European and domestic approaches to the functioning and organization of road networks, urban mobility, and effective use of the space of urbanized territories. The main factors were historical development, scientific-technical progress, an administrative component in the formation of financial flows to developing urban systems, terrain, the process of territories 'urbanization, and the formation of urban agglomerations. These factors had a direct impact on the shape of the modern state of the road network. The process of Intelligent transport systems integration into the system of domestic cities requires complex approaches, in particular, consideration of the parametric structure of elements, application of communicators not only for the control of traffic flows from the outside but also from the inside, which will allow speeding up the information change in the system. One of the elements of the combination of morphologic elements of the urban environment is the practical application of the criterion of street and road infrastructure interaction and the concept of traffic safety profile. This is a result of a combination of all morphological features and variants of their configuration. In current conditions, a new approach in research is necessary to determine criteria and factors of sustainable development of transport systems. This approach allows operatively considering the changes of the external environment, reacting adequately to the changing behaviour of competitors providing services and consumers, and effectively impacting the demand and supply of transport services. A concept of effectiveness is required to consider both the transport system in general and its separate elements. Implementation of progressive methods of system control of transport flows provides, in conditions of rapid motorization and increasing the urbanized territories areas, obtaining the most significant effect in short terms and allows maximal using the possibilities of urban transport networks.
\end{abstract}

Key words: traffic safety profile, central parts of the city, road network, model of informational protection of transport systems, potential threats, risks.

\section{INTRODUCTION}

Increase in car number in the largest cities of Western Europe, which began in 50-s of the last century, took place according to almost the same pattern for all countries: linear growth of the car number to the level of 300-350 auto/1000 citizens after that was growth retardation and stabilization at the level of $550 \pm 50$ auto/1000 citizens [1].

Respectively, the density and intensity of traffic flow also increased as a result of the constant increase of society's motorization level. Urban movement is the result of the necessity of interaction between the planning and structural elements of the city. 
The road network of the cities, which was calculated and constructed based on the much lower traffic intensity, is overloaded. Today's traffic intensity reaches 800 auto/h and more if we consider this indicator as to the average statistical value for cities with over 500 thousand persons.

After analysing the concept of the road network, the transport problem in modern cities can be solved in two ways [2]: by adjusting the city to the needs of transport movement or by adjusting the movement of vehicles to the existing built-up area.

So, intending to increase traffic capacity and safety, many controlled local objects, group forming, increased in the last years. By their presence, the prevailing movement regime of vehicles on the road network of cities, especially their central parts, is group type [3, 4].

Considering the genesis of road network organization, we should pay attention to the concept of "traffic safety". It can be reviewed as a result of the interaction of the rest components. The Law of Ukraine "About traffic movement" and other regulative documents provide such definition of this concept: "it is regulated by legal norms the process of movement, operation of vehicles which excludes the possibility of causing physical or property damage" [5]. That is why the concept of "traffic safety" directly relates to the condition of the road network.

\section{RESEARCH STATEMENT}

The aim of the article is to determine the group of elements that have a direct impact on traffic safety formation and are the cause of the change of its numeric indicators. Morphologic and system methods for the complex assessment of factors that impact traffic safety in central parts of the city were used to investigate cause-effect relationships. For achieving the aim, it is necessary to solve such tasks:

- classification of road network elements;

- analysis of methods of assessment of traffic safety condition;

- usage of system analysis of urban environment parameters to evaluate traffic safety;

- determination of elements of traffic safety profile;

- formation of traffic safety profile with the use of a morphologic matrix of the main components which have an impact on traffic safety in central parts of the city;

- forming the model of informational protection on the road in central parts of the city and determining potential threats and risks.

\section{LITERATURE REVIEW}

The main reasons for the insufficient level of traffic safety provision in Ukraine, in comparison to the appropriate level of European Union countries, are insufficient effectiveness of the system of organizational, planning, and engineering measures, aimed at the improvement of traffic and pedestrian movement organization, creation of safe traffic conditions [6].

Domestic scientists Ye.O. Reitsen [7], M. A. Liakh, O. S. Demianuk [8], V. P. Polishchuk [9] determined the main requirements to the traffic safety on the road network of the city. R. O. Laputyn [10] processed the methods of traffic safety assessment at intersections considering conflict points. V. O. Osypov, in the process of his research, improved the methods of traffic safety assessment on the road sections [11].

Intelligent transport systems, the primary task of which was the organization of informational exchange between vehicles, provide necessary information for avoiding traffic accidents to road users. The scientific community started to pay more attention to solving this task from the end of the Twentieth century as it is one of the ways of solving the abovementioned problems of traffic flows control in central parts of the city.

A dense network of streets and buildings is typical for central parts of cities, which, in its turn, limits the usage of means of control and regulation of traffic flows with maximum effectiveness. That is why in the process of our research, we complemented the given concept and considered it not only as an element 
of urban planning and theory of transport systems and flows but as an element of the informational subsystem of Intelligent transport systems of cities.

The similar complex nature of Intelligent transport systems can be achieved only at the cost of innovation approaches implementation, associated with the involvement of high technology and advanced developments in the field of informational systems, sensor networks, controllers, methods of interaction, and mathematical optimisation methods [12-14].

An Intelligent transport system is an integrated system of people, roads and vehicles which, using current technologies, is designed to significantly contribute to the increase of traffic safety, effectiveness and comfort, and also environmental protection by the realization of optimal movement at the costs of decrease of traffic jams [15].

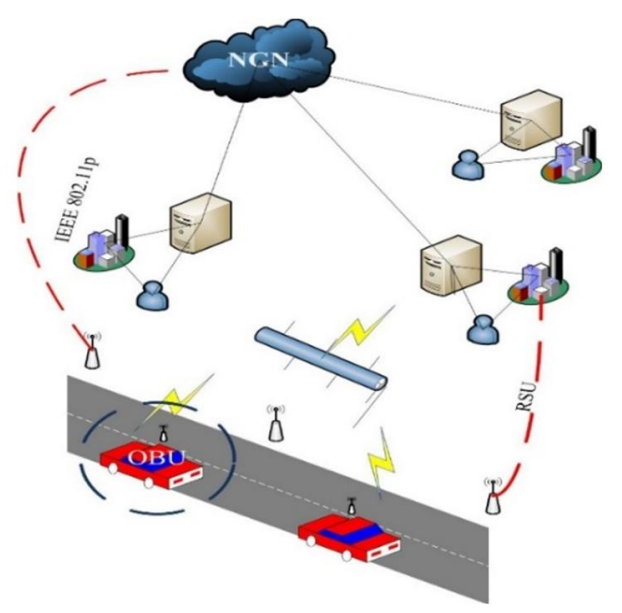

Fig. 1. Architecture of specialized car network VANET

The current level of the development of wireless data transmission technologies allows using informational services from almost any point with the help of small and relatively cheap mobile devices. One of the variants of such technologies was their implementation into control and management of road transport and the development of specialized car networks VANET. The architecture of the VANET network, given in Fig. 1 , involves the interaction of cars with other vehicles and the infrastructure (base) network located along the road.

Thereby, the development and effectiveness of intelligent transport system functioning are based on the provision of connection between vehicles, which, in its turn, requires the usage of sensitive positioning systems and intelligent communication protocols for the information exchange.

Well-known classifications of road network elements do not always provide an opportunity for the precise characteristic of functional parameters of traffic flow organization, forecasting of traffic intensity on a given section. Application of technical means of control and organization of traffic movement does not allow to fully satisfy the demand for information and its dynamic change in time.

Current directions of urban mobility development and construction processes, planning of road network, or its reconstruction use automated systems of traffic flow control. The process of simulation and control of road network loading is related to the proportional distribution of traffic flows on the road network, which is implemented, particularly in the presence of technical means of traffic organization. Formation of the algorithm of traffic flow distribution requires significant financial and technical resources to carry out qualitative research and obtain the necessary informational base.

\section{MAIN PART}

Analysis of current regulations, national standards and construction norms, rights and responsibilities of drivers, passengers, and pedestrians, and also hierarchical structure of executive power and controlling authorities allowed determining the main functional processes of "road network" block.

The components of the functional unit are such processes: formation of traffic flow movement conditions; assessment of road users' interaction; traffic flow simulation taking into account road network conditions; information and communication between road users with the use of modern commutators; assessment of the effectiveness of interaction of all traffic flow and road network components.

Every process includes a list of parameters that describe the system "traffic flow - road infrastructure - environment". For convenience, they are grouped by the belonging to subsystems. Informational and telecommunicational interaction between the system agents, at the request of modernity, has undergone a significant transformation. The exchange of messages between vehicles on the road (V2V) 
with road and urban infrastructure (V2I) is made through the environment of a specialized car network (VANET). This close information communication changed transport on the informational hub and allowed expanding the system "traffic flow - road infrastructure - environment" by adding independent subsystem "information flows and the network" (Table 1) [16].

Table 1

Parametric components of a functional system of road network

\begin{tabular}{|c|c|c|c|}
\hline Subsystem & \multicolumn{3}{|c|}{ Parametric indicators } \\
\hline 1 & \multicolumn{3}{|c|}{2} \\
\hline \multirow{3}{*}{ Traffic flow } & Type of transport & \multicolumn{2}{|l|}{$\begin{array}{l}\text { Vehicular } \\
\text { Pipeline, pneumatic transport }\end{array}$} \\
\hline & Condition of vehicles & $\begin{array}{l}\text { Loaded } \\
\text { Empty }\end{array}$ & $\begin{array}{l}\text { In repair } \\
\text { After repair, etc. }\end{array}$ \\
\hline & $\begin{array}{l}\text { Categories of transported } \\
\text { objects }\end{array}$ & $\begin{array}{l}\text { Passenger flows } \\
\text { Freight and transport flows }\end{array}$ & \\
\hline \multirow{5}{*}{ 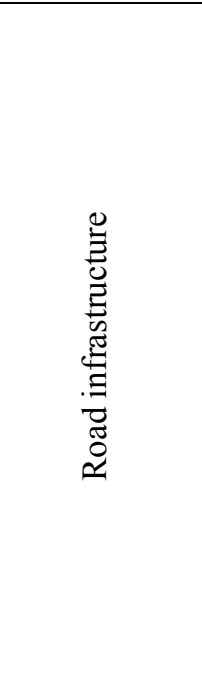 } & Road plan & \multicolumn{2}{|c|}{$\begin{array}{ll}\begin{array}{l}\text { Radius of curve } \\
\text { Angle of rotation }\end{array} & \begin{array}{l}\text { between adjacent } \\
\text { curves }\end{array} \\
\end{array}$} \\
\hline & Road profile & $\begin{array}{l}\text { Longitudinal slope } \\
\text { Radius of convex curves } \\
\text { Radius of concave curves } \\
\end{array}$ & $\begin{array}{l}\text { Length of convex curves } \\
\text { Length of concave curves }\end{array}$ \\
\hline & Cross-section & $\begin{array}{l}\text { Lane width } \\
\text { Shoulder width } \\
\text { Transverse slope } \\
\end{array}$ & $\begin{array}{l}\text { Side lanes width } \\
\text { Lane divider }\end{array}$ \\
\hline & Accidence & $\begin{array}{l}\text { Lighting } \\
\text { Road lanes } \\
\text { Distribution bumpers }\end{array}$ & $\begin{array}{l}\text { Restrictive fences } \\
\text { Informational signs } \\
\text { Road signs }\end{array}$ \\
\hline & Traffic safety & $\begin{array}{l}\text { Technical means of traffic } \\
\text { organization } \\
\text { Quality of road pavement } \\
\text { Safety island } \\
\text { Traffic bay }\end{array}$ & $\begin{array}{l}\text { Parking } \\
\text { Barrier } \\
\text { Pedestrian crosswalk } \\
\text { Pedestrian sidewalk }\end{array}$ \\
\hline \multirow[t]{2}{*}{ Environment } & Climate conditions & $\begin{array}{l}\text { Air temperature } \\
\text { Wind speed } \\
\text { Wind direction } \\
\end{array}$ & $\begin{array}{l}\text { Air humidity } \\
\text { Atmospheric pressure } \\
\text { The level of soil freezing }\end{array}$ \\
\hline & Terrain & Plain & Mountanous \\
\hline \multirow{2}{*}{ 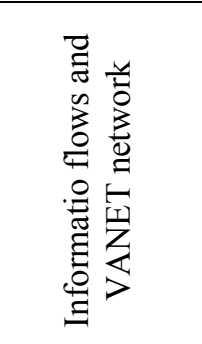 } & Connection & $\begin{array}{l}\text { Dynamic topology } \\
\text { Adaptability of node density } \\
\text { Restriction of movement } \\
\text { Informing about the presence of } \\
\text { obstacles }\end{array}$ & $\begin{array}{l}\text { Decentralized network } \\
\text { Uneven network traffic } \\
\text { Short range communication }\end{array}$ \\
\hline & Attack & $\begin{array}{l}\text { DoS attacks } \\
\text { Insider messages } \\
\text { Broadcast on airSpam }\end{array}$ & $\begin{array}{l}\text { Malicious software } \\
\text { GPS spoofing } \\
\text { Masquerading }\end{array}$ \\
\hline
\end{tabular}

The processes of improvement of qualitative indicators of the society cause the necessity of forecasting the consequences of decisions made for complex systems, which have a human factor of the impact in its composition. Such a decision-making process is formed with the help of the methodology of scenario analysis that comes down to applying the different methods of qualitative analysis in a specific sequence with the establishment of clearly defined relationships.

Swiss-American astrophysicist and specialist in aerospace F. Tsviki [17] had developed methods of morphologic analysis of complex problem solving and bringing them to systematic form. Later, the method was extended and applied by many researchers from Europe and the USA to study the future, in strategies analysis and simulation. 
The macrolevel of the road network system is the main element in assessing the quality of technical means of traffic organization in central parts of the city. Using the morphologic analysis method, let's present systematically possible morphologic structures on a given level (Table 2).

Table 2

Morphologic martrix of traffic safety profile of road network

\begin{tabular}{|c|c|c|c|c|c|c|c|c|c|c|c|c|c|}
\hline \multicolumn{4}{|c|}{ Traffic flow } & \multicolumn{7}{|c|}{ Road network } & \multicolumn{2}{|c|}{ Natural factors } & \multirow{2}{*}{ Informa-tion } \\
\hline 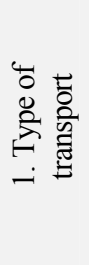 & 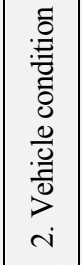 & 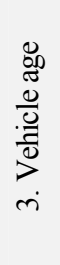 & 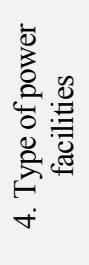 & 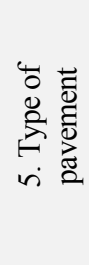 & 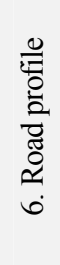 & 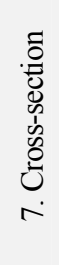 & 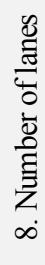 & 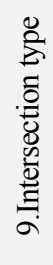 & 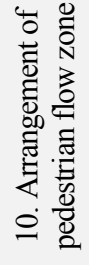 & 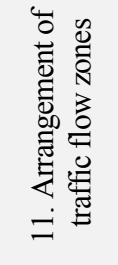 & 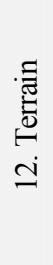 & 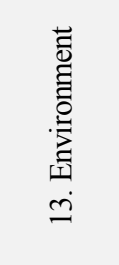 & \\
\hline 1 & 2 & 3 & 4 & 5 & 6 & 7 & 8 & 9 & 10 & 11 & 12 & 13 & 14 \\
\hline 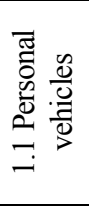 & \multirow{4}{*}{ 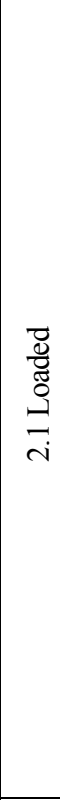 } & \multirow{6}{*}{ 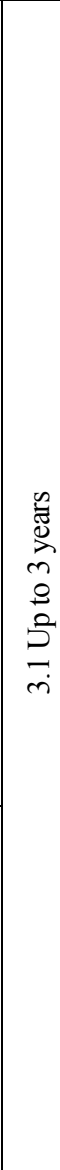 } & \multirow{2}{*}{ 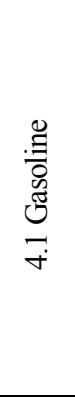 } & \multirow{4}{*}{ 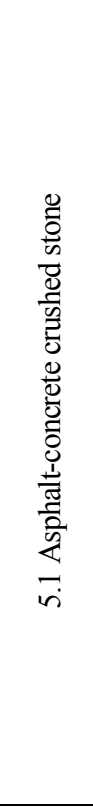 } & \multirow{3}{*}{ 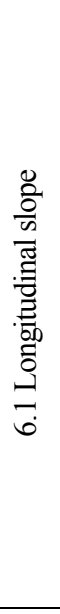 } & \multirow{2}{*}{ 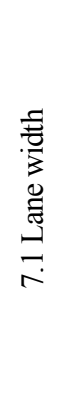 } & \multirow{2}{*}{$\frac{1}{\infty}$} & \multirow{6}{*}{ 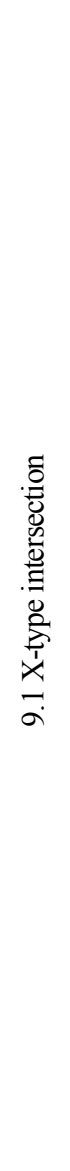 } & 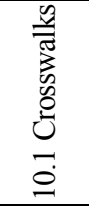 & 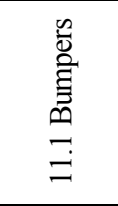 & \multirow{6}{*}{ 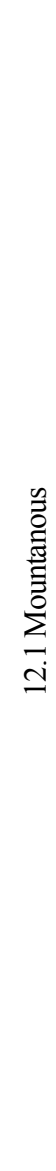 } & 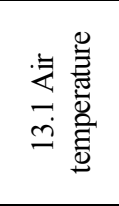 & 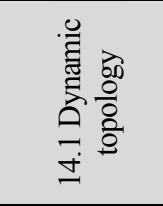 \\
\hline 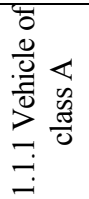 & & & & & & & & & 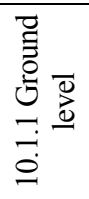 & 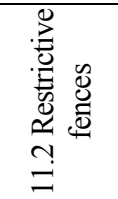 & & 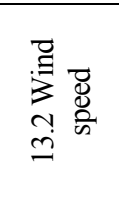 & 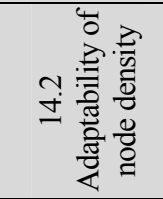 \\
\hline 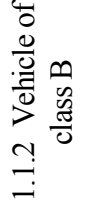 & & & 芯 & & & 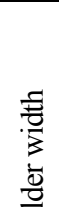 & 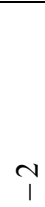 & & 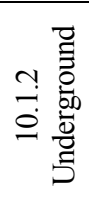 & 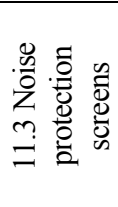 & & 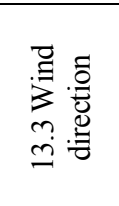 & 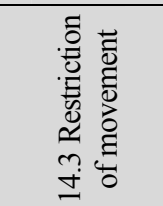 \\
\hline 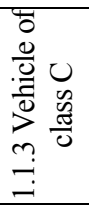 & & & $\begin{array}{l}\vec{A} \\
\text { f }\end{array}$ & & $\overbrace{\overline{0}}^{\mathscr{\nu}}$ & 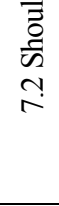 & $\tilde{\infty}$ & & 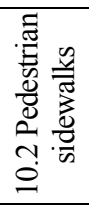 & 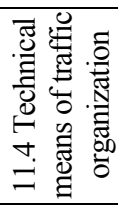 & & 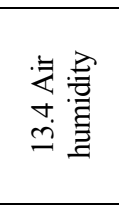 & 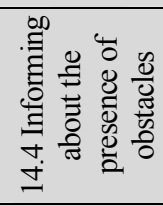 \\
\hline 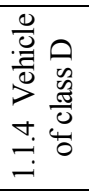 & \multirow{3}{*}{$\begin{array}{l}\text { 言 } \\
\text { 空 } \\
\text { तે }\end{array}$} & & 范 & \multirow{4}{*}{ 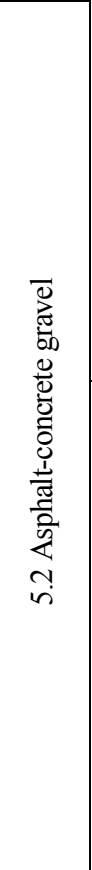 } & 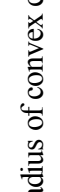 & $\begin{array}{l}\frac{0}{0} \\
\frac{0}{w} \\
0 \\
0 \\
0 \\
0\end{array}$ & & & 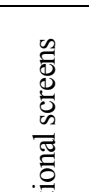 & 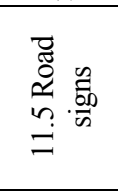 & & 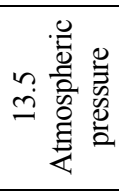 & 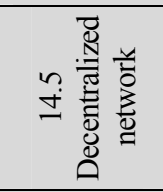 \\
\hline 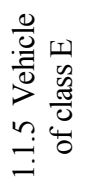 & & & 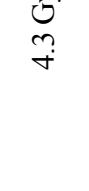 & & $\begin{array}{l}\stackrel{\tilde{ٌ}}{\sim} \\
\tilde{\sigma}\end{array}$ & & $\begin{array}{l}m \\
1 \\
\infty \\
\infty\end{array}$ & & 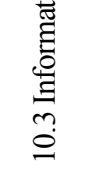 & 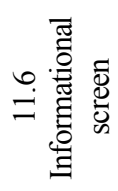 & & 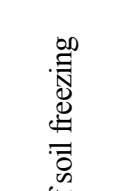 & 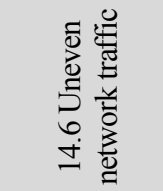 \\
\hline 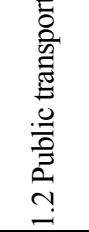 & & \multirow{2}{*}{ 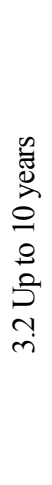 } & \multirow{2}{*}{ 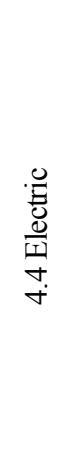 } & & \multirow{2}{*}{ 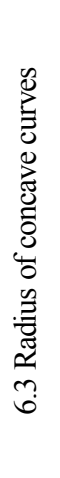 } & \multirow{2}{*}{ 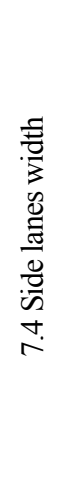 } & & \multirow{2}{*}{ 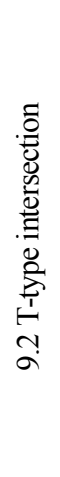 } & 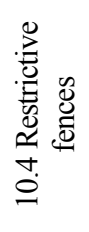 & 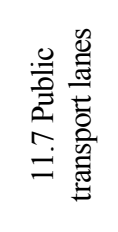 & \multirow{2}{*}{ 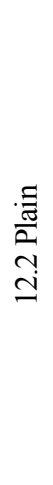 } & 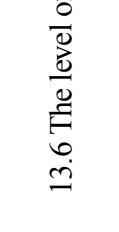 & 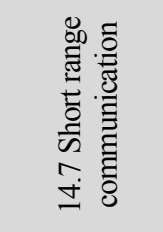 \\
\hline 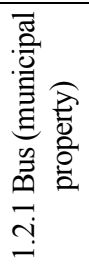 & 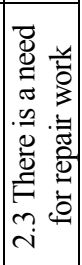 & & & & & & $\begin{array}{l}1 \\
+ \\
\infty\end{array}$ & & 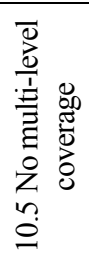 & 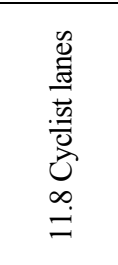 & & 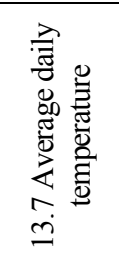 & 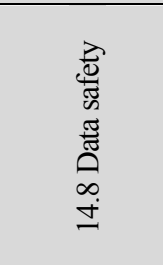 \\
\hline
\end{tabular}


Table continuation 2

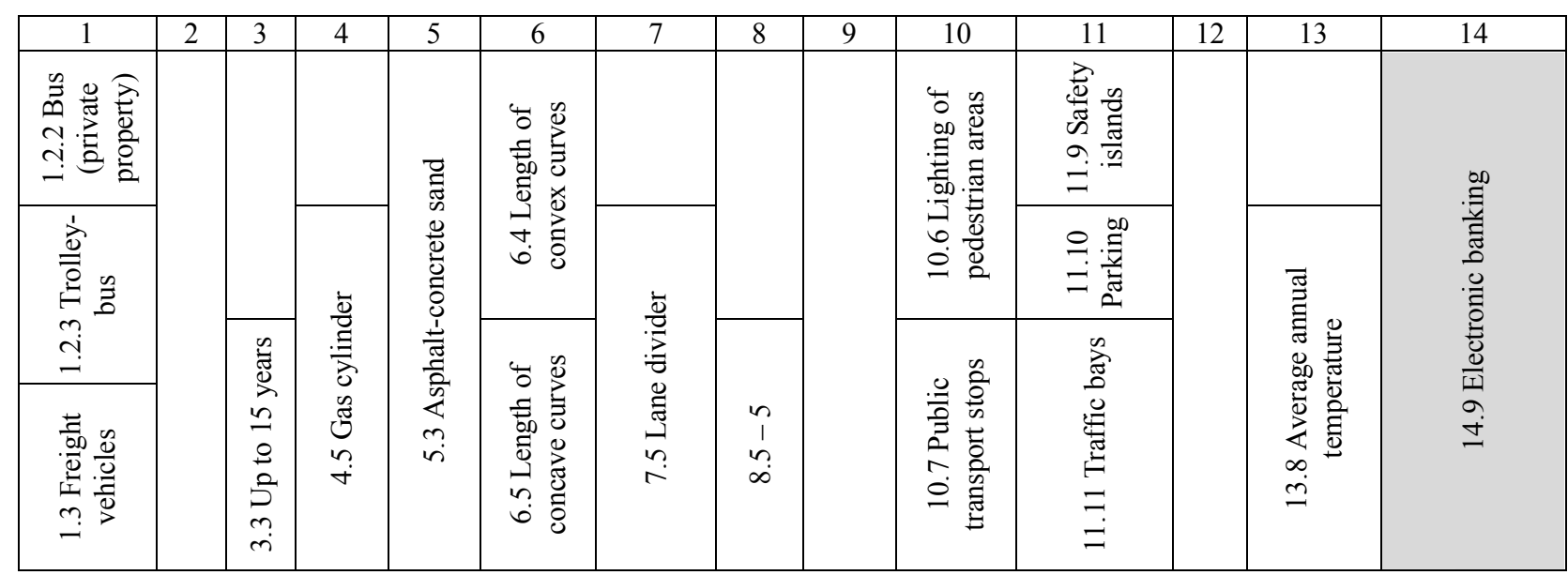

Let's determine the main morphologic features of every functional element and possible variants of their realization. With the help of structure analysis [18], we can propose the schemes of separate components by specified functional elements.

The traffic safety profile results from a combination of all morphologic features and variants of their configuration. The morphologic formula of traffic safety profile will look like this, providing marking of ane feature of every functional component as $x_{i j}$ :

$$
\left[\begin{array}{l}
\left(x_{1.1 .1} ; x_{1.1 .2} ; x_{1.1 .3} ; x_{1.1 .4} ; x_{1.1 .5} ; x_{1.2 .1} ; x_{1.2 .2} ; x_{1.2 .3} ; x_{1.3} ; x_{3.1} ; x_{4.3}\right)+ \\
+\left(x_{5.1} ; x_{7.1} ; x_{8.4} ; x_{10.1 .1} ; x_{10.1 .2} ; x_{11.4} ; x_{11.5}\right)+\left(x_{13.1} ; x_{13.2} ; x_{13.3}\right)
\end{array}\right] .
$$

Having analyzed the morphologic formula of traffic safety profile, we can admit that composite elements of the traffic safety profile of traffic flow contain parameters that characterize the type of vehicle: personal transport $\left(x_{1.1 .1}-x_{1.1 .5}\right)$, public $\left(x_{1.2 .1}-x_{1.2 .3}\right)$, and freight $\left(x_{1.3}\right)$, the age of which does not exceed three years $\left(x_{3.1}\right)$, and the type of power facilities is hybrid $\left(x_{4.3}\right)$.

The constructive elements of road network that have an impact on traffic flow are the type of pavement $\left(x_{5.1}\right)$, which, in its turn, influences the quality of adhesion of road pavement, lane width $\left(x_{7.1}\right)$, and taking into account a significant intensity of vehicles, an important element is a sufficient number of lanes $\left(x_{8.4}\right)$.

Because of the peculiarities of the build-up of central parts of the city, it is appropriate to use signalized ground level and ungerground pedestrian crosswalks $\left(x_{10.1 .1} ; x_{10.1 .2}\right)$ for the regulation of speed characteristics of traffic and pedestrian flows with the use of technical means of traffic organization $\left(x_{11.4}\right)$ and road signs $\left(x_{11.5}\right)$.

Besides, we should remember the impact of the environment $\left(x_{13.1}-x_{13.3}\right)$ and corrections in the operation of vehicles and the properties of road network elements with the change of weather conditions.

Formula (1) is generalized, and it does not consider a range of functional values. That is why we proposed to improve the given morphologic formula with additional components that will change the scheme of achieving the goal. Thus, in the given situation, as we do not have more effective and harmless for the environment vehicles which can be compared by the level of comfort with cars, we should use the existing road networks more effectively and provide their safe functioning. It determines the purpose of traffic management. The requirements about the increase of traffic flow functionality and the provision of traffic safety for vehicles and pedestrians are put forward to the current road networks.

However, as the rapid growth of traffic demand caused the inadmissible increase of traffic volumes and significant traffic jams, the primary functions of road networks were gradually lost, at the same time as their negative impacts on the human life, among which the increase in the number of accidents and environmental pollution, became more noticeable. In this regard, the provision of traffic safety is quite a topical problem in Ukraine [19-21]. 
The question of informational safety nowadays relates to the questions of traffic safety. There is a need for reliable and safe tools for information exchange and the security of software update tools of the car through the wireless networks to reduce risks of unauthorized access to data.

The design of the model of information security includes the stages of the threats assessment of vulnerabilities and risks from unauthorized access to the network [22]. The main threats which have mpact on the reliability of the VANET functioning and violate the main properties of information (confidentiality, integrity, accessibility, observability: refusal of identification, authentication and registration) are given in Table 3 .

Table 3

Threats and risks in informational safety of traffic flow in central parts of the city

\begin{tabular}{|c|c|c|c|c|c|}
\hline \multirow[b]{2}{*}{ № } & \multirow[b]{2}{*}{ Porential threats } & \multicolumn{4}{|c|}{ Risks } \\
\hline & & $\begin{array}{c}\text { Confi- } \\
\text { dentiality }\end{array}$ & $\begin{array}{c}\text { Integ- } \\
\text { rity }\end{array}$ & $\begin{array}{c}\text { Accessi- } \\
\text { bility }\end{array}$ & $\begin{array}{l}\text { Observa- } \\
\text { bility }\end{array}$ \\
\hline 1 & 2 & 3 & 4 & 5 & 6 \\
\hline \multicolumn{6}{|c|}{ 1. Threats of objective nature } \\
\hline 1.1 & Natural phenomena (fire, accident) & & + & + & + \\
\hline 1.2 & Power system failures & & & + & + \\
\hline 1.3 & Computer failures & & & + & + \\
\hline 1.4 & Data media failures and damage & & + & + & \\
\hline 1.5 & Failures in software & & + & + & + \\
\hline \multicolumn{6}{|c|}{ 2. Threats of subjective nature } \\
\hline 2.1 & External threats & & & & \\
\hline 2.1 .1 & Unauthorized connection to technical means & + & & & \\
\hline 2.1 .2 & Unauthorized connection to communication channels & + & & & \\
\hline 2.1 .3 & $\begin{array}{l}\text { Reading the data displayed on the screen, printing, reading } \\
\text { the documents left unattended }\end{array}$ & + & & & \\
\hline 2.1 .4 & $\begin{array}{l}\text { Unauthorized interception of information because of information } \\
\text { leakage due to incidental electromagnetic radiation and } \\
\text { interference }\end{array}$ & + & & & \\
\hline 2.1 .5 & $\begin{array}{l}\text { Unauthorized viewing of information due to the visual-optical } \\
\text { channel }\end{array}$ & + & & & \\
\hline 2.2 & Violation of normal modes of operation & & & & \\
\hline 2.2 .1 & System corruption with computer viruses & & + & + & + \\
\hline 2.2 .2 & $\begin{array}{l}\text { Loss (disclosure) of means of access delimitation (passwords), } \\
\text { magnetic data carriers and backups }\end{array}$ & + & + & + & \\
\hline 2.2 .3 & $\begin{array}{l}\text { Unauthorized changes in hardware, software, information } \\
\text { components, etc. }\end{array}$ & & + & + & + \\
\hline 2.2 .4 & $\begin{array}{l}\text { Use of unauthorized software or modification of software and } \\
\text { information components }\end{array}$ & & + & + & + \\
\hline 2.2 .5 & Damage to data media & & & + & \\
\hline 2.2 .6 & $\begin{array}{l}\text { Login to the system of unauthorized persons (overcoming the } \\
\text { protection system) }\end{array}$ & + & + & + & \\
\hline 2.3 & Staff error & & & & \\
\hline 2.3 .1 & $\begin{array}{l}\text { User errors (implementation and use of programs that are not } \\
\text { necessary for the performance of official duties, launch of } \\
\text { programs that can cause critical changes in the system) }\end{array}$ & + & + & + & \\
\hline 2.3 .2 & $\begin{array}{l}\text { Administrator errors (incorrect configuration and administration } \\
\text { of the security system, operating system, improper disabling } \\
\text { of security features) }\end{array}$ & + & + & + & \\
\hline 2.3 .3 & $\begin{array}{l}\text { Violation of technology of processing, input and output of } \\
\text { information, work with modular storage devices (backups, } \\
\text { standards and distributions) }\end{array}$ & + & + & + & \\
\hline 2.3 .4 & $\begin{array}{l}\text { Careless storage and accounting of documents, media, } \\
\text { databases }\end{array}$ & + & + & + & \\
\hline
\end{tabular}


Table continuation 3

\begin{tabular}{|c|l|c|c|c|c|}
\hline 1 & \multicolumn{1}{|c|}{2} & 3 & 4 & 5 & 6 \\
\hline 2.3 .5 & $\begin{array}{l}\text { Obtaining information from Intelligent Transport Systems } \\
\text { staff by a third party }\end{array}$ & + & & & \\
\hline
\end{tabular}

Due to reviewed questions, scientific sources [23-26] allowed to formulate the main problems of automotive transport in the field of transport of Ukraine, which are the next:

- automotive network does not respond to the existing and perspective freight and passenger flows;

- in conditions of the modern market, transport technologies do not respond to the requirements of the effective automotive transport functioning, interfere the meet of the growing demand for the qualitative transport service, the reduction of transportation cost, optimal use of the existing transport infrastructure;

- the essential assets of transport modes renew at insufficient pace, which contributes to the reduction in the level of safety of automotive process and capacities of separate elements of the transport system;

- transport emissions pollute the environment; transport communications are overloaded, the indicators of transport process safety do not respond to the worldwide level, there are many accidents with injured, etc. Total damage from the negative consequences of automotive activity increases annually and is about $7-8 \%$ from the Gross Domestic Product;

- there is a significant lag of road network development pace from the motorization of society;

- problems of provision of traffic safety and anti-terrorism stability of the transport system have been exacerbated.

\section{CONCLUSIONS}

Solving current problems requires rapid, compromise, and effective solutions. One of the instruments in everyday practice is the system approach that uses the methodologic basis of system analysis.

Decomposition of the city transport system on the main components of the subsystem as a result of the analysis has allowed determining the central cause-effect relationships and impact factors, mechanisms of realization of tasks set, and the input and output parameters of the system. It allowed obtaining the decomposition of all elements of the city transport system, which affect the processes of urban mobility, traffic and pedestrian flows, traffic organization, and indicators of safety and accidence.

Traffic safety profile has been formed based on a morphologic matrix composed with the help of decomposed elements of system analysis. The general morphologic formula was developed, and a situational formula that gives a precise assessment of the safety of road network, traffic or pedestrian flow depending on the component parameters was given. It contributes to the development of different situational profiles of traffic safety.

Impact of informational telecommunication threats on the traffic safety was determined as potential threats and risks that allows designing the model of traffic safety in central parts of the city and including its parameters to traffic safety profile.

In result of the conducted research, we determined a range of criteria of urban traffic flow effectiveness, which will be used in further research to improve the road network and increase traffic safety in central parts of the city.

\section{References}

1. Eurostat (2019) All countries compared for Transport.: Number of passenger cars per 1000 inhabitants. Retrieved from: https://ec.europa.eu/eurostat/statistics-explained/index.php/Passenger_cars_in_the_EU_2019. (in English)

2. Bakulich O.O., Polishchuk V. P., (Ed) (2016) Orhanizatsiia ta rehuliuvannia dorozhnoho rukhu [Organization and regulation of traffic]. Kyiv. (in Ukrainian) 
3. Kapskyi D. V. \& Losyn L. A. (2019) Transport v planyrovke horodov. Ch. 1: Transportnoe planyrovanye: matematycheskoe modelyrovanye [Transport planning of cities. Part 1. Transport planning: mathematical modeling]. Mynsk: BNTU. (in Russian)

4. Khrutba V. O. \& Komar K. V. (2018) Analiz implementatsii ukrainskoho zakonodavstva do Yevropeiskoi normatyvno-pravovoi bazy u sferi bezpeky dorozhnoho rukhu [Analysis of the implementation of Ukrainian legislation to the European regulatory framework in the field of road safety]. Naukovo-tekhnichnyi zbirnyk Avtomobilni dorohy i dorozhnie budivnytstvo [Automobile roads and road construction. Scientific and technical journal], 103. 155-166. (in Ukrainian)

5. Pro dorozhnii rukh: $N$ 3353-XII. [About traffic: $N$ 3353-XII] Retrieved from: https://zakon.rada.gov.ua/ laws/show/3353-12. (in Ukrainian)

6. Hlobalnyi plan zdiisnennia: Desiatylittia dii z bezpeky dorozhnoho rukhu na 2010-2020 roky [Global Implementation Plan: A decade of road safety action for 2021-2020] Retrieved from: http://www.who.int/roadsafety/ decade_of_action/plan/plan_russian.ua. (in Ukrainian)

7. Tolkov A. V. (2019) Orhanyzatsyia dvyzhenyia na avtomahystraliakh y $v$ horodakh [Organization of traffic in cars in cities]. Vladymyr. (in Russian).

8. Myshkovych, O. (2016). Analiz sotsialno-ekonomichnykh problem zabezpechennia bezpeky dorozhnoho rukhu v Ukraini [Analysis socio-economic problems to ensure road safety in Ukraine]. Sotsialno-ekonomichni problemy i derzhava [Socio-economic problems and the state]. 15 (2), 120-124. (in Ukrainian).

9. Statystyka DTP v Ukraini za period z 01.01.2020 po 31.12.2020. [Statistics of road accidents in Ukraine for the period from 01.01.2020 to 31.12.2020] Retrieved from: http://patrol.police.gov.ua/statystyka. (in Ukrainian)

10. Shvydkist rukhu ta bezpeka na dorohakh [Speed and road safety] Retrieved from: https://cedem.org.ua/wpcontent/uploads/2018/02/NS-2018_1_7-SHvydkist.pdf. (in Ukrainian)

11. Mistobuduvannia. Planuvannia i zabudova miskykh i silskykh poselen. [Urban Planning. Planning and development of urban and rural settlements.]. (2013). DBN ISO 360-92. Kyiv (in Ukrainian).

12. Korjagin, S. \& Klachek, P. (2017). Innovative development of intelligent transport systems based on biocybernetical vehicle control systems. Transportation Research Procedia, 20, 326-333. doi: 10.1016/j.trpro.2017.01.038 (in English).

13. Zear. A., Singh, P. K. \& Singh, Y. (2016) Intelligent Transport System: A Progressive Review Indian Journal of Science and Technology, 9(32), 1-8 doi: 10.17485/ijst/2016/v9i32/100713 (in English).

14. Giovanni, P., Severino, A. \& Canale, A. (2019) Special Issue "New Perspectives in Intelligent Transportation Systems and Mobile Communications towards a Smart Cities Context" Future Internet, 11(11), 228; doi: 10.3390/fi11110228 (in English).

15. Paul, A., Chilamkurti, N., Daniel, A., \& Rho, S. (2017) Intelligent Vehicular Networks and Communications Fundamentals, Architectures and Solutions. Todd Green ( $p .227)$ (in English).

16. Ocheretenko S. V. (2009) Orhanizatsiia miskoho rukhu v umovakh vysokoi avtomobilizatsii [Organization of urban traffic in conditions of high motorization]. Komunalne hospodarstvo mist: zbirnyk naukovykh prats [Municipal economy of cities], 88. 285-290 (in Ukrainian).

17. Chechenova L.M. (2020) Systemnyi podkhod k rassmotrenyiu perspektyvnykh napravlenyi razvytyia transportnykh system [A systematic approach to the consideration of promising areas of development of transport systems]. Biulleten rezultatov nauchnykh issledovanyi [Bulletin of scientific research results]. 3, 109-121. (in Russian).

18. Jacyna, M., \& Pyza, D. (2019). Decision-making problems in shaping the sustainable development of the transport system. AUTOBUSY-Technika, Eksploatacja, Systemy Transportowe, 24(6), 61-67. doi: 10.24136/atest. 2019.126 (in English).

19. Stepanov O. V. (Ed) (2018) Bezpeka avtotransportu v transportnomu protsesi [Safety of motor transport in the transport process]. Rarytety Ukrainy (in Ukrainian).

20. Pro skhvalennia Transportnoi stratehii Ukrainy na period do 2020 roku [About approval of transport strategy of Ukraine for the period till 2020] Retrieved from: https://zakon.rada.gov.ua/laws/show/2174-2010-r\#Text. (in Ukrainian)

21. Pro skhvalennia Transportnoi stratehii Ukrainy na period do 2030 roku [About approval of transport strategy of Ukraine for the period till 2030] Retrieved from: https://zakon.rada.gov.ua/laws/show/430-2018-r\#Text. (in Ukrainian)

22. Hapon A. O., Fedorchenko V. M. \& Poliakov A. O. (2020) Pidkhody do pobudovy modeli zahroz dlia analizu bezpeky vidkrytoho prohramnoho koda [Approaches to the construction of the threat model for analysis of 
security of the open software code]. Systemy obrobky informatsii [Information processing systems], 1 (160), 128-135 doi: 10.30748/soi.2020.160.17 (in Ukrainian).

23. Zhuravleva, N. A. (2019). Kontseptualni osnovy otsinky efektiv vid rozvytku proektiv vysokoshvydkisnykh transportnykh system na osnovi mahnitnoi levitatsii [Conceptual basis for assessment of effects of magnetic levitation-based high-speed transport systems projectsdevelopment]. Transportni systemy ta tekhnolohii [Transportation Systems and Technology], 5(1), 89-102. doi: 10.17816/transsyst20195189-102 (in Russian).

24. Horev A. Ye. (2016) Informatsyonnye tekhnolohyy na transporte [Information technologies on transport]. Moskva (in Russian).

25. Gamero, N., Silla, I., Sainz-González, R., \& Sora, B. (2018). The influence of organizational factors on road transport safety. International journal of environmental research and public health, 15(9), 1938. doi: 10.3390/ijerph15091938 (in English).

26. Pidmurniak, O. \& Baiura, D. (2020). Stratehii rozvytku orhanizatsiinykh zmin na pidpryiemstvakh avtomobilnoi haluzi Ukrainy [Strategies for the development of organizational change in the enterprises of the automotive industry of Ukraine]. Naukovyi prostir: aktualni pytannia, dosiahnennia ta innovatsii [Scientific space: current issues, achievements and innovations] (pp. 37-39). - Kharkiv. doi: 10.36074/02.10.2020.v1.07 (in Ukrainian).

Received 28.09.2021; Accepted in revised form 20.10.2021.

\title{
ФОРМУВАННЯ ПРОФІЛЮ БЕЗПЕКИ РУХУ У ЦЕНТРАЛЬНИХ РАЙОНАХ МІСТА ТА ЙОГО ІНФОРМАЦІЙНИЙ ЗАХИСТ
}

\begin{abstract}
Анотація. Сьогодні існує відмінність європейського та вітчизняного підходів до функиіонування та організаиії вулично-дорожньої мережі, міської мобільності, а також ефективного використання простору урбанізованих територій. Основними факторами були: історичний розвиток, науково-технологічний прогрес, адміністративна складова, у формуванні фінансових потоків для розвитку міських систем, рельєф місиевості, прочес урбанізаиії територій та утворення міських агломерацій. Ці фактори прямо вплинули на формування сучасного стану вулично-дорожньої мережі. Процес інтеграчії інтелектуальних транспортних систем у систему українських міст потребуе комплексних підходів, зокрема врахування параметричної структури елементів, застосування комунікаторів не тільки для контролю транспортних потоків ззовні, а й всередині, щьо дозволить пришвидиити обмін інформацією в системі. Одним із елементів поєднання морфологічних елементів міського середовища є практичне застосування критерію очінки взаємодї вуличної та дорожньої інфраструктури та поняття профіль безпека руху. Це результат поєднання усіх морфологічних ознак між собою та варіанти їх конфігураиії. У сучасних умовах для визначення критеріїв і факторів стійкого розвитку транспортних систем потрібний новий підхід у дослідженнях, щзо дає змогу оперативно враховувати зміни зовнішнього середовища, адекватно реагувати на поведінку конкурентів надання послуг і споживачів, яка змінюється, та ефективно впливати на попит $і$ пропозицію транспортних послуг. Поняття ефективності необхідно розглядати щодо транспортної системи загалом, так $і$ до окремих ї̈ елементів. Впровадження прогресивних методів системного управління транспортними потоками забезпечуе в умовах швидкої автомобілізації та збільшення площ урбанізованих територій отримання найбільшого ефекту в стислі терміни $і$ дає змогу максимально використовувати можливості міських дорожсніх мереж.
\end{abstract}

Ключові слова: профіль безпеки руху, иентральні райони міста, вулично-дорожня мережа, модель захисту інформачї̈ транспортних систем, потенційні загрози, ризики. 